УДК 622. 276.53

DOI: $10.31471 / 1993-9973-2021-1(78)-43-50$

\title{
ДОСЛІДЖЕННЯ ТА АНАЛІЗ СПОСОБІВ РЕМОНТУ НАСОСНИХ ШТАНГ
}

\author{
Б. В. Копей, О. Р. Мартинець
}

\author{
ІФНТУНГ; 76019, м. Івано-Франківськ, вул. Карпатська, 15; тел. (03422) 42331, \\ e-mail: kopeyb@nunq.edu.ua
}

\begin{abstract}
На даний час питання підвищення надійності та довговічності нафтогазового обладнання набули особливої актуальності. Колона насосних штанг (КНШ) є однією із найслабших ланок штангових свердловинних насосних установок (ШСНУ). Саме насосні штанги різко обмежують їх надійність і довговічність. Це пов'язано із надзвичайно важкими умовами роботи насосних штанг. Змінні навантаження розтягу та згину, вплив корозійно-активного середовища, тертя до колони насосно-компресорних труб (особливо в похилоспрямованих свердловинах), відкладення асфальто-смоляно-парафінових речовин та інші експлуатаційні фактори призводять до появи та інтенсивного розвитку корозійно-втомних тріщин $i$, як наслідок, до руйнування колони штанг. Такі аварії пов'язані з великими матеріальними затратами на ремонт і відновлення експлуатації свердловин. Близько 70\% нафтових свердловин в Україні експлуатується штанговими свердловинними насосними установками (ШСНУ). Однією з основних проблем, пов'язаних з експлуатацією обладнаних ШСНУ свердловин, є частий вихід з ладу насосних штанг (НШ). Проведений аналіз існуючих способів ремонту насосних шттан дасть можливість визначити ефективний метод їх ремонту. Запропоновано комбінований метод ремонту штанг обробкою металевими щчітками та нанесенням модифікованого поліуретанового покриття. Проведені експерименти відрізків натурних штанг показують, щэо металеві щіітки є ефективним засобом очищення $і$ зміцнення штанг, особливо тих, які вже були в експлуатації. Встановлено, щзо метод комбінованого зміцнення обробкою щітками та нанесенням поліуретанового покриття додатково підвищує величину G-критерію на 20\%. Модифіковане поліуретанове покриття дасть змогу підвищити стійкість штанги до стирання при терті до колони насосно-компресорних труб, з однієї сторони, та попередити відкладання асфальто-смоляно-парафінових речовин на тілі штанг, з іншої.
\end{abstract}

Ключові слова: насосні штанги, навантаження, корозія, деформація, металеві щітки, поліуретанове покриття.

В настоящее время вопросы повышения надежности и долговечности нефтегазового оборудования имеют особую актуальность. Колонна насосных штанг (КНШ) является одной из самых слабых звеньев штанговых скважинных насосных установок (ШСНУ). Именно насосные штанги резко ограничивают их надежность и долговечность,что связано с чрезвычайно сложными условиями работы насосных штанг. Переменные нагрузки растяжения и изгиба, влияние коррозионно-активной среды, трение о колонну насосно-компрессорных труб, особенно в наклонних скважинах, отложения асфальто-смолисто-парафиновых веществ и другие эксплуатационные факторы становятся причиной возникновения и интенсивного развития коррозионно-усталостных трещчин и, как следствие, к разрушению колонны штанд. Такие аварии связаны с большими материальными затратами на ремонт и восстановление эксплуатации скважин. Порядка $70 \%$ нефтяных скважин в Украине эксплуатируется штанговыми скважинными насосными установками (ШСНУ). Одной из основных проблем, связанных с эксплуатацией оборудованных ШСНУ скважин, является частый выход из строя насосных итанг (НШ). Проведен анализ существующих способов ремонта насосных итанг позволит определить эффективный метод их ремонта. Предложен комбинированный метод ремонта штанг путем обработки металлическими щетками и нанесением модифицированного полиуретанового покрытия. Проведенные эксперименты отрезков натурных штанг показывают, что металлические щетки является эффективным средством очистки и упрочнения штанг, особенно бывщих в эксплуатации. Установлено, что метод комбинированного упрочнения обработкой щетками и нанесением полиуретанового покрытия дополнительно повыцает величину G-критерия на 20\%. Модифицированное полиуретановое покрытие позволит повысить устойчивость итанги к истиранию при трении о колонну насоснокомпрессорных труб, с одной стороны, и предупредить отложение асфальто-смолисто-парафиновых веществ на теле штанг, с другой.

Ключевые слова: насосные штанги, нагрузка, коррозия, деформация, металлические щетки, полиуретановое покрытие. 
At this time, the question increase the reliability and durability of natural gas equipment acquired special urgency. The column of pump rods (KNSh) is one of the weakest links of rod well pumping units (SHSNU). It is the pump rods that sharply limit their reliability and durability. This is due to the extremely difficult operating conditions of the pump rods. Variable tensile and bending loads, the influence of corrosive environment, friction on the column of tubing, especially in inclined wells, deposition of asphalt-resin-paraffin substances and other operational factors lead to the appearance and intensive development of corrosion-fatigue cracks and, as, to the destruction of the column of rods. Such accidents involve high material costs for repairing and restoring wells. About $70 \%$ of oil wells in Ukraine operated downhole rod pumping units (SHSNU). One of the main problems associated with the operation of wells equipped SHSNU is frequent failure of the rod (NSH). The analysis of existing methods of repair rod will enable identify effective method of repair. A combined method of sucker rod repair by treatment with metal brushes and application of a modified polyurethane coating is proposed. Experiments of sections of full-length rods show that metal brushes are an effective means of cleaning and strengthening the rods, especially those that have already been in operation. It is established that the method of combined hardening by brushing and polyurethane coating further increases the value of the G-criterion by 20\%. The modified polyurethane coating will increase the abrasion resistance of the rod when it contacts against the column of tubing on one side and prevent the deposition of asphalt-resin-paraffin substances on the body of the rods on other side.

Keywords: pump rods, repair, loading, corrosion, deformation, metal brushes, polyurethane coating.

\section{Актуальність проблеми}

Велика кількість штанг в процесі експлуатації виходять з ладу, але ці відмови і пошкодження не $\epsilon$ критичними, тому насосна штанга може використовуватися після проведеного ремонту повторно [1]. Такими пошкодженнями $\epsilon$ незначне зношування, викривлення тіла штанги, відкладання асфальто-смолистих та парафінових речовин і солей [2-4]. Тому важливою задачею $\epsilon$ ефективне повторне використання насосних штанг після проведеного їх ремонту.

\section{Виділення невирішених частин проблеми}

Не досліджено ефективні методи очищення насосної штанги від асфальто-смолистих та парафінових речовин і солей та методи їх розчинення. На даний час не визначено, до якої міри допускається зношення тіла насосної штанги.

\section{Аналіз останніх досліджень і публікацій}

Відомі способи відновлення насосних штанг, коли штангу 3 допустимими експлуатаційними пошкодженнями зміцнюють дробоструминною обробкою та нанесенням металізаційного цинкового покриття [1]. А.С.178780 передбачає послідовну пластичну деформацію та металізацію штанг. Недоліком даного способу є недовговічність цинкового покриття внаслідок розчинення в пластовій мінералізованій воді і зниження ефективності ремонту штанги.

Найбільш близьким способом до запропонованого $є$ нанесення на оброблену дротяними щітками насосних штанг склотканинної стрічки [2]. Проте з часом склотканинна стрічка відшаровується, і корозійне середовище проникає до тіла штанги.

\section{Постановка задачі досліджень}

Тому була поставлена задача визначити ефективний спосіб ремонту насосних штанг, який забезпечував би повторне ефективне використання насосних штанг після проведеного ї ремонту.

\section{Основний матеріал дослідження}

У промисловій практиці відомі способи зміцнення штанг поверхневою пластичною деформацією (ППД) в умовах ремонтних баз технічного обслуговування як нових, так і експлуатованих насосних штанг ШН19, ШН22 i ШH25 [5].

Зазначений ППД реалізується при планетарному обкачуванні роликами галтельні частини (або всього) тіла штанги. Планетарне обкачування забезпечує підвищення циклічної довговічності, твердості і міцності за рахунок поверхневого наклепу найбільш навантаженого шару тіла штанги і створення в ньому залишкових напружень стиску. Наклеп збільшує міцність поверхневого шару, а створені залишкові напруження стиску зменшують значення робочих напружень, що виникають при експлуатації в найбільш небезпечній поверхневій зоні, і нейтралізують негативну роль в цій зоні концентраторів напружень, які $є$ причиною зародження втомних тріщин. Такий комплексний вплив ППД істотно збільшує втомну міцність і ресурс роботи НШ і значно ефективніший за спосіб зміцнення розтягуванням із закручуванням НШ. При зміцненні розтяганням відбувається зміцнення і одночасно підвищується крихкість матеріалу i, як наслідок, не збільшується довговічність. Крихкий метал більш чутливий до концентраторів напружень. 

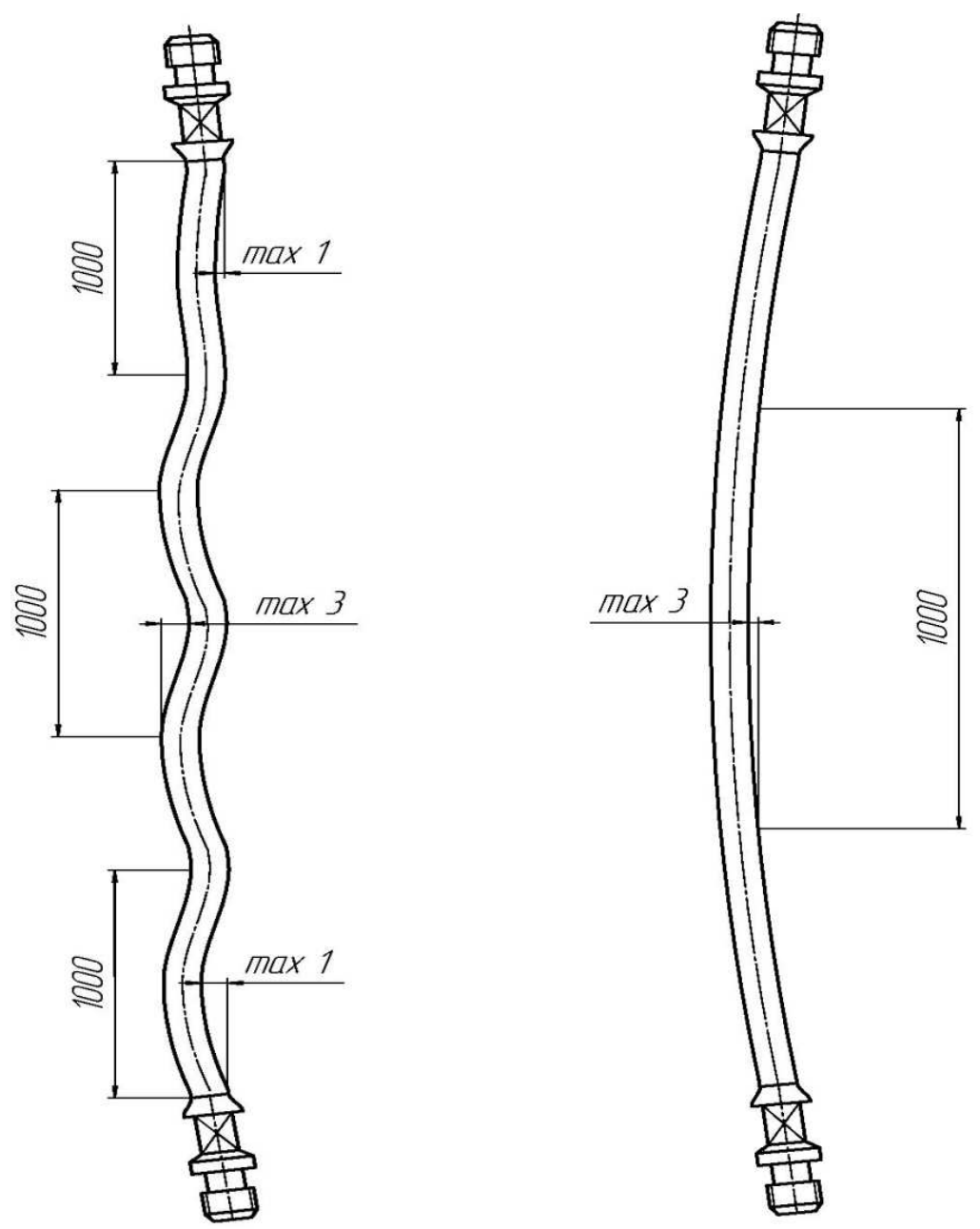

Рисунок 1 - Кривизна насосної штанги

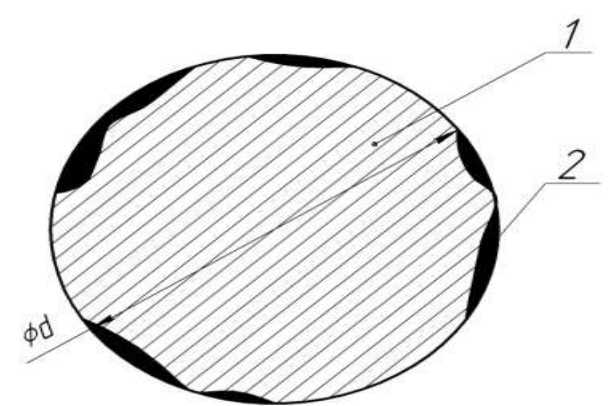

1 - тіло штанги; 2 - пошкодження, які виникають в процесі експлуатаиіі

Рисунок 2 - Штанга $з$ пошкодженнями у розрізі

Обкатування роликами дозволяє також видаляти окалину і різко знижувати висоту мікронерівностей поверхневого шару, що спрощує візуальний контроль НШ. На гладкій, блискучій поверхні після обкатування роликами добре проявляються поздовжні і поперечні мікротріщини з розкриттям від 5 до 10 мкм та інші невидимі під шаром окалини дефекти. Поздовжні i поперечні мікротріщини шириною до 5 мкм усуваються внаслідок нейтралізації («заліковування») і не служать концентраторами для розвитку втомних тріщин. Мікротріщини значних розмірів під впливом деформуючого інструме- нту розгладжуються та утворюють добре виражену дефектну ділянку.

Перед обкатуванням насосні штанги нагрівають до температури, при якій матеріал штанги набуває можливість пластичної деформації. Зазвичай температура нагрівання становить 950- $1150^{\circ} \mathrm{C}$. При цьому спочатку передній кінець штанги затискають в валках прокатного стану, а інша іiі частина обертається у вільному стані. Для обкатування використовують тривалкову машину зі швидкістю прокатки 100$110 \mathrm{~mm} / \mathrm{c}$. Частота обертання валків становить 70-72 об/хв, максимальний діаметр валків для 
калібрування - 88-90 мм, довжина бочки валка 84-86 мм. Збільшення довжини тіла штанги при пластичній деформації перебуває у межах від 1,30 до 3,36 м. Штанга видовжується за рахунок зменшення товщини (діаметру). При початковому діаметрі штанги 22 мм домагаються діаметрів штанг 19, 16, 15, 12 мм. Даним способом організувують виробництво штанг діаметром 19-12 мм, використовуючи в якості вихідного матеріалу (заготовки) насосні штанги, непридатні для ремонту будь-якою іншою відомою технологією. Після обкатування штанги піддають гартуванню у воді, відпуску, нормалізації або охолодженню на повітрі.

Існує спосіб часткового відновлення початкових властивостей насосної штанги шляхом обрізання дефектних головок насосної штанги для отримання з іï тіла вкорочених заготовок відповідної якості, які використовується для виготовлення існуючими методами нової насосної штанги укороченої довжини.

Недоліком зазначеного способу ремонту насосних штанг $є$ значна кількість вибракуваних насосних штанг, які відходять в металобрухт.

"Металургійний завод" ім. А.К.Сєрова застосовує спосіб виготовлення насосної штанги 3 приварними головками, який можна використовувати під час ремонту насосної штанги. При цьому окремо виготовлені елементи насосної штанги (тіло і головки) з'єднуються між собою методом зварювання тертям.

Існує спосіб, що включає відрізання непридатного до експлуатації різьбового з'єднання із упорним буртом і з'єднання методом зварювання тертям нової заготовки з подальшою іiі механічною обробкою. При цьому з метою відновлення працездатності насосної штанги непридатне до експлуатації різьбове з'єднання відрізають по упорному бурту, причому відношення ширини решти бурту до його діаметра становить 0,22-0,27, а після приварювання нової заготовки проводять механічну обробку упорного бурта.

Для підвищення жорсткості конструкції в напрямку дії робочого навантаження та підвищення показника утилізації дефектних насосних штанг використовується інший спосіб ремонту насосних штанг. Це видалення дефектних ділянок, заміна їх на справні, з'єднання методом зварювання. Проводять попередню обробку поверхонь і стиків до необхідних розмірів ділянок, термообробку і чистову обробку поверхонь і стиків до номінальних розмірів 3 необхідною чистотою обробки.
3 тіл насосних штанг, вибракуваних за відомими методами діагностики, проводиться вибірка придатних до ремонту і подальшої експлуатації мірних ділянок, достатніх для формування 3 них головок насосних штанг або тіла насосної штанги.

3 отриманих мірних ділянок існуючими способами формують головки насосних штанг, в яких потім виконують наскрізні осьові отвори заданого діаметра.

Отримані головки насосних штанг приварюють до тіла насосної штанги, виготовленої 3 труби необхідного розміру з наскрізним поздовжнім отвором. А в разі відсутності труби необхідного розміру 3 наскрізним поздовжнім отвором тіло насосної штанги формують 3 отриманих мірних ділянок шляхом виконання в них наскрізного поздовжнього отвору і подальшого з'єднання їх шляхом зварювання, наприклад, тертям.

Поверхні і стики отриманої насосної штанги піддають обробці до необхідних розмірів ділянок, термообробці і чистовій обробці поверхонь і стиків до номінальних розмірів ділянок 3 необхідною чистотою обробки [6,7].

Після закінчення обробки у внутрішню порожнину відремонтованої насосної штанги на всю іï довжину встановлюється попередньо напружений розтягуванням елемент, кінці якого закріплюються в головках насосної штанги будь-яким відомим способом, наприклад за допомогою роз'ємного (різьбового) або нероз'ємного (запресованого) з'єднань.

Розглянемо спосіб ремонту насосних штанг, який полягає у використанні обертових щіток для очищення та зміцнення поверхні відпрацьованих насосних штанг, подальшого нанесення склопластикової стрічки та захисного поліуретанового покриття. Після обробки щітками і дробоструминної обробки наносять модифіковане поліуретанове покриття, яке містить наповнювачі, що забезпечують підвищену зносостійкість покриття, а поверхня має властивість, що запобігає відкладанню парафінів. Для ремонту штанг, які були в експлуатації, необхідно провести відповідне очищення поверхні від смолисто-парафінистих речовин, солей, продуктів корозії, окалини з метою подальшого дробоструминного зміцнення i нанесення покриттів багатофункціонального призначення [8]. Для цього доцільно використовувати металеві обертові щітки. Установка УВЩ25 забезпечує подачу штанг по рольгангу в зміцнюючу головку, обробку іiі тіла і складування на стелажах. Установка (рис. 3) складається 3 блоку обробки 4 насосної штанги 5, металевих 


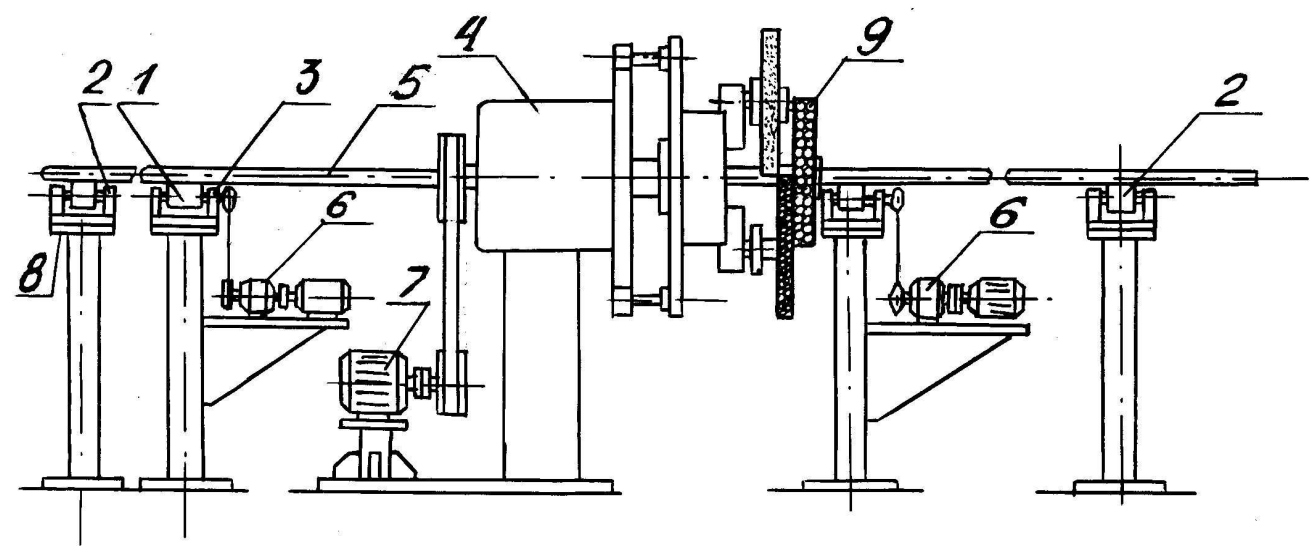

Рисунок 3 - Установка УВЩ-25 для зміцнення і очищення насосних штанг металевими обертовими щітками

щіток 9, поворотних плит 8, підтримуючих 2 i приводних 3 рольгангів, головними елементами яких є ролики 1, а також системи електроприводів 3 ланцюговою 6 і пасовою 7 передачами.

Однією $з$ особливостей установки є наявність магнітного ролика, змонтованого на поворотній плиті 8, 3 можливістю встановлення його під кутом до осі деталі, що транспортується. В поєднанні з глобоїдною конфігурацією опорної поверхні ролика це забезпечує одночасно 3 поступальним рухом обертання оброблюваного вироба навколо своєї осі. Магнітний ролик зібраний з трьох потужних кільцевих ферито-барієвих магнітів діаметром 85 мм і чотирьох полюсників 3 магнітом'якого матеріалу. Вся система зроблена в вигляді глобоїду загальною довжиною вздовж осі близько 200 мм. В процесі експлуатації магнітна система практично не розмагнічується. Використання постійних магнітів для ролика дозволяє досягти необхідної сили притягування переміщуваної штанги до опорної поверхні, що усуває нерівномірність руху і проковзування. Це, в свою чергу, позитивно впливає на якість зміцнення. Подаючий рольганг має два-три магнітних приводних ролики і три-чотири опорних гумовометалевих. Блок обробки (рис. 4) має три вузли металевих щіток 1, рівномірно розташованих по колу і послідовно насаджених на валу 2. Металевий канатний дріт і кільця масою 50 г використовуються як ударні елементи. Металевий дріт при обертанні щітки і набіганні на тіло штанги вдаряється до іiі поверхні, виконуючи при цьому дві функції: очищення штанги від окалини, бруду, смолисто-парафінистих речовин і зміцнення поверхні тіла за рахунок утворення напружень стиску.

Ударні елементи в вигляді кілець діаметром 60 мм, товщиною 5 мм забезпечують гли-

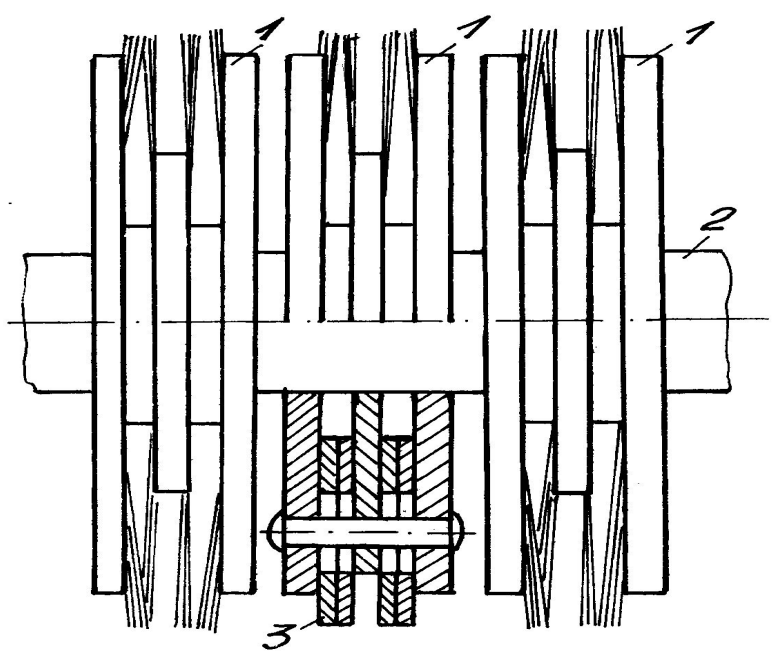

1 -металева щітка, 2 - вал, 3 - ударні кільия

Рисунок 4 - Блок обробки насосних штанг металевими обертовими щітками

бокий поверхневий наклеп штанги, що додатково підвищує іiї опір корозійно-втомному руйнуванню. При збиранні щіток використовують до 20 кілець. Кільця насаджені на валу діаметром 20 мм 3 можливістю радіального переміщення відносно своєї осі приблизно на 10 мм. Кільця виготовляють зі сталі 60Г або 60С2.

Працює установка УВЩ-25 таким чином. Насосну штангу 5 (див. рис. 3) встановлюють на рольганги 2 і 3. Через ланцюгову передачу 6 від електропривода ролики рольгангу 3 приводяться в обертання, викликаючи переміщення деталі з блоку обробки 4. Привод металевих щіток (електродвигун 3 пасовою передачею 7) розташовано таким чином, щоб їх обертання не викликало опору обертанню штанги, яке передається магнітними роликами при іiї транспортуванні. Після блоку обробки деталь по рольгангах передається до місця складування зміцнених штанг. 
Технічна характеристика установки i іï робочих органів

Частота обертання металеві щіток $\mathrm{n}, \mathrm{xB}^{-1}$ 1300

Маса ударного елемента $\mathrm{m}$, г 50

Діаметр дроту d, мм . 1,6

Густина ворсу, шт./см² $20-25$

Швидкість подачі штанги, мм/с ..65

Час зміцнення однієї штанги, хв 2-3

Обслуговуючий персонал, чол.

Для оцінки ефективності зміцнення металевими щітками, що обертаються, 3 ударними елементами у вигляді кілець, проводили натурні випробування насосних штанг діаметром 22 мм зі сталі $20 \mathrm{H} 2 \mathrm{M}$.

В результаті обробки штанг на установці УВЩ-25 глибина пластичного деформування склала 600-800 мкм, шорсткість поверхні $R_{z}=40-80$ мкм, залишкові осьові напруження стиску - близько 600-700 МПа.

Зміцнені штанги випробовували на опір втомному руйнуванню при змінному консольному згині 3 частотою навантаження 15,2 Гц. Корозійне середовище - мінералізована пластова вода [1]. Контроль втомної тріщини проводили за допомогою ультразвукового дефектоскопа ДУК-6В.

В результаті наклепу щітками довговічність насосних штанг при роботі в корозійноактивному середовищі зростає в 2,5 рази. При цьому суттєво гальмується швидкість розвитку тріщини в початковий період роботи штанг. Величина G-критерію насосних штанг діаметром 22 мм при роботі в пластовій воді після ППД металевими щітками зростає в 1,5-2 рази (рис. 5).

Проведені експерименти показують, що металеві щітки можуть бути ефективним засобом очищення i зміцнення штанг, особливо експлуатованих [7].

Для оцінки ефективності зміцнення металевими щітками, що обертаються, 3 ударними елементами у вигляді кілець проводили натурні випробування насосних штанг діаметром 22 мм зі сталі 20Н2М.В результаті обробки штанг на установці УВЩ-25 глибина пластичного деформування склала 600-800 мкм, шорсткість поверхні $R_{z}=40-80$ мкм, залишкові осьові напруження стиску - близько 600-700 МПа. Зміцнені штанги випробовували на опір втомному руйнуванню при змінному консольному згині 3 частотою навантаження 15,2 Гц. Корозійне середовище - 3\%-ний водний розчин $\mathrm{NaCI} 3$ періодичним насиченням сірководнем до грани-
Характеристика пластових вод Долинського родовищ Прикарпаття

\begin{tabular}{|c|c|}
\hline $\begin{array}{c}\text { Характеристика } \\
\text { пластових вод родовища }\end{array}$ & $\begin{array}{c}\text { Північна } \\
\text { Долина }\end{array}$ \\
\hline $\begin{array}{l}\mathrm{Na}^{++}, \mathrm{K}^{+}, \text {мг/л } \\
\text { мг екв/л } \\
\% \text { мг екв }\end{array}$ & $\begin{array}{l}40486 \\
1756 \\
44,12\end{array}$ \\
\hline $\begin{array}{l}\mathrm{Ca}^{++}, \quad \text { мг/л } \\
\text { мг екв/л } \\
\% \text { мг/л }\end{array}$ & $\begin{array}{c}4103 \\
205 \\
5,14\end{array}$ \\
\hline $\begin{array}{l}\mathrm{Mg}^{++}, \quad \text { мг/л } \\
\text { мГ екв/л } \\
\% \text { мг екв }\end{array}$ & $\begin{array}{c}385 \\
29 \\
0,73 \\
\end{array}$ \\
\hline $\begin{array}{l}\mathrm{Cl}^{-}, \text {мг/л } \\
\text { мг екв/л } \\
\% \text { мГ екв }\end{array}$ & $\begin{array}{c}70290 \\
1982 \\
49,81\end{array}$ \\
\hline $\begin{array}{l}\mathrm{SO}_{4}^{--}, \text {мг/л } \\
\text { мГ екв/л } \\
\% \text { мг екв }\end{array}$ & $\begin{array}{l}115 \\
2,39 \\
0,06 \\
\end{array}$ \\
\hline $\begin{array}{l}\mathrm{HCO}_{3}, \mathrm{мг} / л \\
\text { мг екв/л } \\
\% \text { мг екв }\end{array}$ & $\begin{array}{c}61 \\
1,0 \\
0,025\end{array}$ \\
\hline $\begin{array}{l}\mathrm{J}^{-}, \text {мг/л } \\
\text { мГ екв/л } \\
\% \text { мг екв } \\
\end{array}$ & $\begin{array}{l}100 \\
0,79 \\
0,02 \\
\end{array}$ \\
\hline $\begin{array}{l}\text { Br 5- 0, мг/л } \\
\text { мг екв/л } \\
\% \text { мг екв }\end{array}$ & $\begin{array}{l}282 \\
3,52 \\
0,09 \\
\end{array}$ \\
\hline $\mathrm{B}_{2} \mathrm{O}_{3}$, мг/л & 300 \\
\hline Мінералізація, г/л & 115,7 \\
\hline Густина, кг/м ${ }^{3}$ & 1060 \\
\hline $\mathrm{pH}$ & 5,23 \\
\hline
\end{tabular}

Примітка: хімічний аналіз проведено в НДПІ ПАТ "Укрнафта"

чної концентрації. Контроль втомної тріщини проводили за допомогою ультразвукового дефектоскопа ДУК-6В.

Ступінь пошкодження $D$ оцінювали за площами зон корозійної втоми в небезпечному перерізі тіла штанги:

$$
D=F_{6} / F_{H},
$$

де $F_{\kappa}$ - площа зони корозійно-втомного руйнування;

$$
F_{H} \text { - номінальна площа перерізу. }
$$

За лінійну функцію, яка описує процес корозійно-втомного руйнування, було прийнято рівняння Почтенного Є.К.:

$$
G=G_{o}-\left(G_{o}-G_{\kappa}\right) N_{n} / N_{\kappa},
$$

де $G_{o}=/ \lg D_{o} /$ - критерій опору корозійній втомі в початковий момент реєстрації тріщин, 


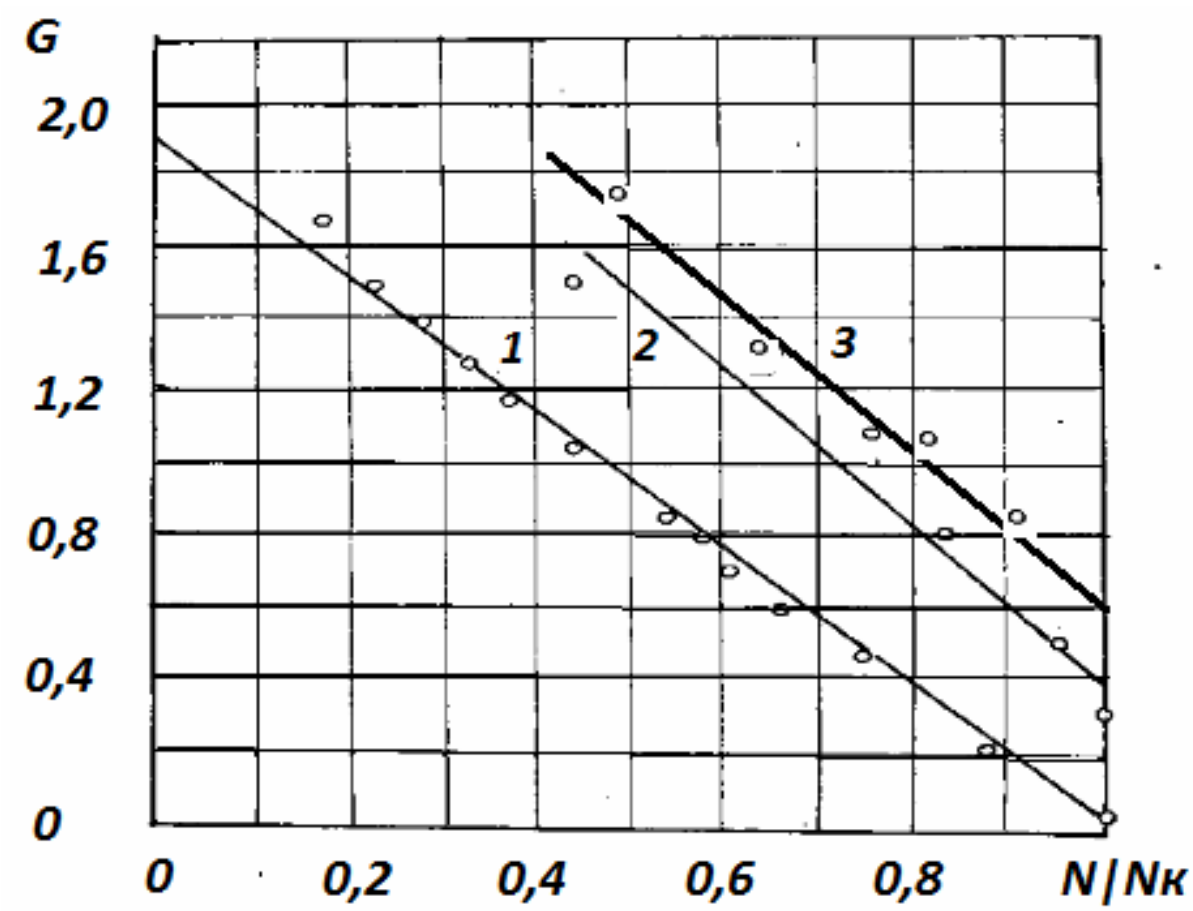

1 - незміџнені штанги; 2 - після оброблення металевими щітками, 3 - комбіноване оброблення щітками та нанесення поліуретанового покриття

Рисунок 5 - Залежність ступеня пошкодження насосних штанг діаметром 22 мм зі сталі 20H2M за G-критерісм при роботі в пластовій воді

$G_{\kappa}$ - критерій опору корозійній втомі в момент кінцевої поломки,

$N_{n}, N_{\kappa}$ - поточна і кінцева кількість циклів навантаження з'єднання. рис. 5.

Результати експерименту наведені на

Крива 1 побудована за результатами вимірювань параметрів тріщини ультразвуковим контролем. Крива 2 описує розвиток тріщини в зміцненій щітками штанзі, крива 3 - розвиток тріщин після комбінованої обробки щітками та нанесенням поліуретанового покриття.

Отримано рівняння лінійної регресії, яке описує кінетику корозійно-втомного руйнування насосної штанги:

$$
G=1,93-2,01 N / N_{\kappa} .
$$

Слід зауважити, що ступінь вихідного пошкодження незміцненої штанги становить $G_{o}=1,9$, а критерій опору корозійній втомі штанги в момент доламу $G_{\kappa}=0,05$.

Аналізуючи криві 1 і 2 , можна зробити висновок, що критерій $G$ для незміцнених штанг, які випробовувалися в корозійному середовищі, на $35-40 \%$ нижчий, ніж для зміцнених.

В результаті наклепу щітками довговічність насосних штанг при роботі в сірководневому середовищі зростає в 2,5 рази. При цьому суттєво гальмується швидкість розвитку трі- щини в початковий період роботи штанг. Величина $G$-критерію насосних штанг діаметром 22 мм при роботі в пластовій воді після ППД металевими щітками зростає в 1,5-2 рази, а після комбінованого зміцнення обробкою щітками та нанесенням поліуретанового покриття [9] ще на $20 \%$.

\section{Висновки}

1. Для підтримання насосних штанг в робочому стані на об'єктах експлуатації потрібно забезпечувати систему технічного обслуговування, слідкувати за виконанням правил експлуатації обладнання, вказаних в технічних умовах.

2. Удосконалення технологічних параметрів під час ремонту насосних штанг має велике значення для підвищення ресурсу роботи обладнання.

3. Через значні дефекти велика кількість насосних штанг вибраковується. Потрібно знайти більш прогресивні методи ремонту, які б забезпечували надійність роботи відновленого обладнання.

4. Діагностика стану насосних штанг буде більш достовірною за умови якісного очищення їх від асфальто-смолисто-парафінових відкладів і солей. 
5. Проведені експерименти показують, що металеві щітки можуть бути ефективним засобом очищення і зміцнення штанг, особливо тих, які вже були в експлуатації. Запропоновано новий метод [7] комбінованого зміцнення обробкою щітками та нанесенням поліуретанового покриття, який підвищую величину G-критерію ще на $20 \%$.

6. За допомогою отриманих результатів можна планувати періодичність дефектоскопії колон насосних штанг i обмежити частоту їx обривів під час експлуатації.

\section{Лimepamypa}

1. Копей Б. В., Копей В. Б., Копей І. Б. Насосні штанги свердловинних установок для видобування нафти. Івано-Франківськ: ІФНТУНГ, 2009. $406 \mathrm{c}$.

2. Копей Б.В., Кузьмін О.О. Онищук С.Ю. Обладнання для попередження відкладень асфальтосмолистих речовин, парафіну та піску. Івано-Франківськ: ІФНТУНГ, 2014. 216 с.

3. Нелюбов Д. В., Важенин Д. А., Петелин А. Н. Асфальтосмолопарафиновые отложения Аганского месторождения. Нефтехимия. 2011. № 6. C. 410-413.

4. Агаев С. Г., Гребнев А. Н. Влияние физико-химических свойств асфальто-смоло-парафиновых отложений (АСПО) на парафинизацию скважин. Материаль всероссийской научно-технической конференции «Нефть и Газ Западной Сибири». 2009. 392 с.

5. Патент 2356718 (RU) Способ ремонта штанг насосных методом пластической деформации / Богатов Николай Александрович Опубл. 27.05.2009.

6. ГОСТ 13877-96. Межгосударственный стандарт. Штанги насосные и муфты штанговые. Технические условия. Киев: Госстандарт Украины, 2002. $28 \mathrm{c}$.

7. API Spec. $11 B$. Sucker rods, $26^{\text {th }}$ Edition. 1998. $58 \mathrm{p}$.

8. Фаерман И. Л. Штанги для глубинных насосов. Баку: Азовнефтеиздат, 1955. 323 с.

9. Патент на корисну модель № 116217. Спосіб ремонту насосних штанг за допомогою металевих обертових щіток / Копей Б. В., Мартинець О. Р., Ісса Салман. Заявл. и 201612230 від 01.12.2016. Опубл. 10.05.2017, Бюл. № 9.

\section{References}

1. Kopei B. V., Kopei V. B., Kopei I. B. Nasosni shtanhy sverdlovynnykh ustanovok dlia vydobuvannia nafty. Ivano-Frankivsk: IFNTUNH, 2009. 406 p. [in Ukrainian]

2. Kopei B. V., Kuzmin O. O., Onyshchuk S. Iu. Obladnannia dlia poperedzhennia vidkladen asfaltosmolystykh rechovyn, parafinu ta pisku. Ivano-Frankivsk: IFNTUNH, 2014. 216 p. [in Ukrainian]

3. Nelyubov D. V., Vazhenin D. A., Petelin A. N. Asfaltosmoloparafinovyie otlozheniya Aganskogo mestorozhdeniya. Neftehimiya. 2011. No 6. 103 p. [in Russian]

4. Agaev S. G., Grebnev A. N. Vliyanie fiziko-himicheskih svoystv asfalto-smolo-parafinovyih otlozheniy (ASPO) na parafinizatsiyu skvazhin. Materialyi vserossiyskoy nauchnotehnicheskoy konferentsii «Neft $i$ Gaz Zapadnoy Sibiri». 2009. 392 p. [in Russian]

5. Patent 2356718 (RU). Sposob remonta shtang nasosnykh metodom plasticheskoy deformatsii / Bogatov Nikolay Aleksandrovich Opubl. 27.05.2009.

6. GOST 13877-96. Mezhgosudarstvennyiy standart. Shtangi nasosnyie i muftyi shtangovyie. Tehnicheskie usloviya. Kiev: Gosstandart Ukrainyi, 2002. 28 p. [in Russian]

7. API Spec. 11B. Sucker rods, 26th Edition. 1998. $58 \mathrm{p}$.

8. Faerman I. L. Shtangi dlya glubinnyih nasosov: Baku: Azovnefteizdat, 1955. 323 p. [in Russian]

9. Patent na korysnu model No 116217 Sposib remontu nasosnykh shtanh za dopomohoyu metalevykh obertovykh shchitok / Kopey B.V., Martynets O.P., Issa Salman. Zayavl. u 201612230 vid 01.12.2016. Opubl. 10.05.2017, Byul. No 9. 